\title{
FAKTOR-FAKTOR YANG MEMPENGARUHI NILAI PERUSAHAAN PADA PERUSAHAAN MAKANAN DAN MINUMAN TAHUN 2015-2018
}

\author{
Oleh : Marisa Ayu Nurrohmah \\ Marisayu44@gmail.com \\ (Program Studi Akuntansi, FE Universitas Islam Batik Surakarta)
}

\begin{abstract}
Abstrak-Tujuan penelitian ini adalah untuk mengetahui pengaruh likuiditas, struktur modal, profitabilitas, pertumbuhan perusahaan dan firm size terhadap nilai perusahaan. Metode penelitian yang digunakan adalah statistik deskriptif. Populasi pada penelitian ini adalah perusahaan makanan dan minuman pada Bursa Efek Indonesia pada 2015-2018. Teknik pengambilan sampel menggunakan metode purposive sampling dan mendapatkan sampel sebanyak 12 perusahaan dari beberapa kriteria. Sumber data adalah data sekunder. Metode analisis data menggunakan uji asumsi klasik dan analisis linear berganda menggunakan SPSS 21. Hasil analisis ini menunjukkan bahwa profitabilitas berpengaruh terhadap nilai perusahaan. Sementara likuiditas, struktur modal, pertumbuhan perusahaan dan firm size tidak memiliki pengaruh terhadap nilai perusahaan.
\end{abstract}

Kata Kunci : Likuiditas, DER, Profitabilitas, Pertumbuhan Perusahaan, Firm Size

Abstract-This study aims to determine the effect of liquidity, capital structure, Profitability, Company Growth and firm size on firm value.The research method used is descriptive statistics. The population in this study are food and beverage companies on the Indonesia Stock Exchange in 2015-2018. The sampling technique used purposive sampling method and obtained a sample of 12 companies from several criteria. Data source is secondary data. The data analysis method uses the classic assumption test and multiple linear analysis using SPSS 21. The results of this analysis show that profitability influences firm value. While liquidity, capital structure, company growth and firm size have no influence on firm value.

Keywords : Liquidity, DER, Profitability, Company Gtowth, Firm Size

\section{PENDAHULUAN}

Semua perusahaan yang ada di dunia sudah pasti menginginkan laba dalam menjalankan kegiatan operasionalnya untuk melanjutkan kegiatan operasional perusahaan.
Selain itu perusahaan terutama yang memiliki saham di perusahaan menginginkan keuntungan yang tinggi untuk mendapatkan deviden yang besar. Semakin besar deviden yang dibagikan oleh perusahaan tentu akan 
menjadi nilai tambah bagi perusahaan dan mendorong investor untuk melakukan investasi di perusahaan. Nilai perusahaan pada dasarnya dapat diukur melalui beberapa aspek, salah satunya adalah dengan harga pasar saham perusahaan karena harga pasar perusahaan mencerminkan

penilaian investor terhadap perusahaan secara keseluruhan.

Harga pasar saham meningkat maka akan meningkatkan kekayaan para pemegang saham. Menurut Weston dan Brigham (1993), struktur modal yang optimal merupakan salah satu cara untuk meningkatkan harga pasar saham. Perusahaan dengan struktur modal yang tidak baik dan hutang yang sangat besar akan memberikan beban berat kepada perusahaan sehingga perlu diusahakan suatu keseimbangan yang optimal dalam menggunakan kedua sumber tersebut sehingga dapat memaksimalkan nilai perusahaan. Hidayah and Rahmawati (2019) Hasil penelitian ini menunjukkan bahwa Struktur Modal tidak berpengaruh terhadap nilai perusahaan. Natalia, Erlina, Iskandar Muda (2019 ) Hasil Penelitian ini menunjukkan bahwa Struktur Modal Berpengaruh terhadap nilai perusahaan.

Berdasarkan uraian diatas, penulis bertujuan untuk melakukan penelitian dengan judul "Faktorfaktor yang mempengaruhi Nilai Perusahaan Pada Perusahaan

\section{Makanan dan Minuman tahun 2015-2018."}

\section{METODE PENELITIAN}

Penelitian ini bertujuan untuk meneliti pengaruh struktur modal, profitabilitas, pertumbuhan perusahaan dan firm size terhadap nilai perusahaan pada perusahaan makanan dan minuman yang terdaftar di Bursa Efek Indonesia tahun 2015-2018. Jenis Penelitian ini adalah penelitian sekunder. Populasi dalam penelitian 12 Perusahaan, dengan sampel 48 perusahaan menggunakan metode purposive sampling. Metode analisis data dalam penelitian ini adalah statistik deskriptif, uji asumsi klasik, dan analisis regresi linear berganda.

1. Variabel Dependen

a. Kinerja Keuangan

Nilai suatu perusahaan yang dapat diukur dari harga saham perusahaan saat ini.

$P E R=\frac{\text { HARGA SAHAM SAAT INI }}{\text { LABA BERSIH PER SAHAM }}$

2. Variabel Dependen

a. Likuiditas

menunjukkan likuiditas

perusahaan yang diukur dengan membandingkan aktiva lancar terhadap hutang lancar atau hutang jangka pendek (Keown : 2008).

$C R=\frac{\text { AKTIVA LANCAR }}{\text { HUTANG JK PENDEK }} \times 100 \%$ b. Struktur Modal perbandingan atau imbangan pendanaan jangka panjang perusahaan yang ditunjukkan oleh perbandingan hutang 
jangka panjang terhadap modal sendiri.

$$
D E R=\frac{\text { Total Debt }}{\text { total equity }}
$$

c. Profitabilitas

kemampuan perusahaan dalam menghasilkan laba selama periode tertentu dan juga memberikan gambaran tentang tingkat efektifitas manajemen dalam melaksanakan kegiatan operasinya.

$$
\text { profitability }=\frac{\text { operating profit }}{\text { net revenues }}
$$

d. Company Growth

Peningkatan atau penurunan total aset yang dimiliki oleh perusahaan.
Pertumbuhan perusahaan

$$
=\left(\mathrm{TA}_{\mathrm{t}}-\mathrm{TA}_{\mathrm{t}-1}\right) / \mathrm{TA}_{\mathrm{t}-1} \mathrm{X} 100 \%
$$

e. Firm Size

Ukuran yang dipakai untuk mencerminkan besar kecilnya perusahaan yang didasarkan kepada total asset perusahaan.

$$
\text { Ln (Total Aset) }
$$

\section{HASIL DAN PEMBAHASAN}

\section{Uji Statistik Deskriptif}

Analisis statistik deskriptif untuk melihat gambaran secara umum dari data yang didapatkan pada penelitian. Pada penelitian ini pengukurannya memusatkan pada nilai minimum, maximum, mean dan standar deviasi masing-masing variabel.

Tabel 1. Uji Statistik Deskriptif

\begin{tabular}{|c|c|c|c|c|c|}
\hline & $\mathbf{N}$ & Minimum & Maximum & Mean & $\begin{array}{c}\text { Std. } \\
\text { Deviation }\end{array}$ \\
\hline NP & 48 & .01 & 28.88 & 2.3742 & 5.65036 \\
CR & 48 & .00 & .05 & .0167 & .01326 \\
DER & 48 & .06 & 1.74 & .7692 & .46082 \\
PRF & 48 & .01 & .53 & .1198 & .10550 \\
GROWTH & 48 & .01 & 3.88 & .4392 & .76211 \\
FZ & 48 & 9.36 & 13.98 & 12.3357 & 1.08325 \\
$\begin{array}{c}\text { Valid N } \\
\text { (listwise) }\end{array}$ & 48 & & & & \\
\hline
\end{tabular}

Sumber: Diolah dari SPSS 21, 2020

Uji Asumsi Klasik

Uji asumsi klasik dilakukan melalui beberapa tahap dan beberapa macam uji. Pengujian tersebut meliputi uji normalitas, uji normalitas, uji multikolinearitas, uji autokorelasi dan uji heteroskedastisitas. 
Tabel 2. Uji Normalitas

\begin{tabular}{|ll|c|lc|}
\hline & & $\begin{array}{l}\text { Unstandardized } \\
\text { Residual }\end{array}$ & Syarat & Kesimpulan \\
\hline $\begin{array}{l}\text { Asymp. Sig. (2- } \\
\text { tailed) }\end{array}$ & 0.10 & $\begin{array}{l}>0,05 \\
\text { Normal }\end{array}$ & Data Terdistribusi \\
\hline
\end{tabular}

Sumber: Diolah dari SPSS 21, 2020

Dari table 2 dapat diketahui bahwa nilai signifikasi Kolmogrov Smirnov (K-S) adalah 0,10, artinya bahwa nilai tersebut lebih besar dari 0,05 yang berarti data terdistribusi normal.

Tabel 3. Uji Multikolinearitas

\begin{tabular}{|c|c|c|c|c|c|}
\hline Variabel & Tolerance & Std & VIF & Std & Keterangan \\
\hline Likuiditas & 0,727 & $>0,10$ & 1,357 & $<10$ & $\begin{array}{l}\text { Tidak terjadi } \\
\text { Multikolinieritas }\end{array}$ \\
\hline Struktur modal & 0,388 & $>0,10$ & 2,580 & $<10$ & $\begin{array}{l}\text { Tidak terjadi } \\
\text { Multikolinieritas }\end{array}$ \\
\hline Profitabilitas & 0,386 & $>0,10$ & 2,589 & $<10$ & $\begin{array}{l}\text { Tidak terjadi } \\
\text { Multikolinieritas }\end{array}$ \\
\hline $\begin{array}{l}\text { Pertumbuhanperusa } \\
\text { haan }\end{array}$ & 0,237 & $>0,10$ & 4,226 & $<10$ & $\begin{array}{l}\text { Tidak terjadi } \\
\text { Multikolinieritas }\end{array}$ \\
\hline Firm Size & 0,946 & $>0,10$ & 1,057 & $<10$ & $\begin{array}{l}\text { Tidak terjadi } \\
\text { Multikolinieritas }\end{array}$ \\
\hline
\end{tabular}

Sumber: Diolah dari SPSS 21, 2020

Berdasarkan hasil uji Size memiliki nilai tolerance $>0,1$ dan multikolinearitas pada table 3 dapat nilai VIF $<10$, maka dapat diketahui bahwa variabel Likuiditas, disimpulkan bahwa semua variabel Struktur Modal, Profitabilitas, tidak terjadi multikolinearitas. pertumbuhan perusahaan dan Firm

Tabel 4. Uji Heteroskedastisitas

\begin{tabular}{|c|c|c|c|c|}
\hline Variabel & Sig & Syarat & \multicolumn{2}{|l|}{ Kesimpulan } \\
\hline Likuiditas & 0,062 & $>0,05$ & $\begin{array}{l}\text { Tidak } \\
\text { Heteroskedastisitas }\end{array}$ & Terjadi \\
\hline Struktur Modal & 0,120 & $>0,05$ & $\begin{array}{l}\text { Tidak } \\
\text { Heteroskedastisitas }\end{array}$ & Terjadi \\
\hline Profitablitas & 0,145 & $>0,05$ & $\begin{array}{l}\text { Tidak } \\
\text { Heteroskedastisitas }\end{array}$ & Terjadi \\
\hline Pertumbuhan Perusahaan & 0,083 & $>0,05$ & $\begin{array}{l}\text { Tidak } \\
\text { Heteroskedastisitas }\end{array}$ & Terjadi \\
\hline Firm Size & 0,174 & $>0,05$ & $\begin{array}{l}\text { Tidak } \\
\text { Heteroskedastisitas }\end{array}$ & Terjadi \\
\hline
\end{tabular}

Sumber: Diolah dari SPSS 21, 2020 
Berdasarkan hasil uji perusahaan dan Firm Size memiliki heteroskedastisitas pada table 4 nilai signifikansi > 0,05, maka dapat menunjukkan bahwa variabel disimpulkan bahwa tidak terjadi Likuiditas, Struktur Modal, heteroskedastisitas dalam model ini. Profitabilitas, pertumbuhan

Tabel 5. Uji Autokorelasi

\begin{tabular}{|l|l|l|l|}
\hline DU & $\begin{array}{l}\text { Watson } \\
\text { Wurbin }\end{array}$ & $<4-D U$ & Keterangan \\
\hline 1.670 & $<1.938$ & $<2.330$ & Tidak Terjadi Autokorelasi \\
\hline
\end{tabular}

Sumber: Diolah dari SPSS 21, 2020

Tabel 6. Uji Analisis Regresi Linear Berganda

\begin{tabular}{|l|l|}
\hline$S$ & \\
\hline Eonstant & \\
Pikuiditas & 8,786 \\
Struktur Modal & 116,580 \\
Profitabilitas & 3,990 \\
Pertumbuhan Perusahaan & $-10,239$ \\
Firm Size & 2,177 \\
$d$ & 0,520 \\
\hline
\end{tabular}

Sumber: Diolah dari SPSS 21, 2020

Berdasarkan hasil pengujian tabel 6, maka didapat persamaan regresi sebagai berikut :

$$
\begin{aligned}
\mathrm{Y}= & 8,786+116,580 \mathrm{X}_{1}+3,990 \mathrm{X}_{2}-10,239 \mathrm{X}_{3}+ \\
& 2,177 \mathrm{X}_{4}+0,520 \mathrm{X}_{5}+\mathrm{e} \\
& \text { Persamaan regresi linier }
\end{aligned}
$$
berganda yang telah terbentuk tersebut diatas mempunyai pengertian sebagai berikut :

1. Konstanta yang diperoleh sebesar 8,786 menyatakan bahwa jika semua variabel independen bernilai 1 persen, maka nilai perusahaan akan naik sebesar 8,786

2. Koefisien Regresi Variabel Likuiditas bernilai 116,580. Hal ini berarti apabila variabel likuiditas naik sebesar 1 persen dengan asumsi variabel yang lainnya tetap, maka diikuti kenaikan nilai perusahaan sebesar 116,580.

3. Koefisien Regresi Variabel struktur modal bernilai 3,990. Hal ini berarti apabila variabel struktur modal naik sebesar 1 persen dengan asumsi variabel yang lainnya tetap, maka diikuti kenaikan nilai perusahaan sebesar 3,990

4. Koefisien Regresi Variabel Profitabilitas bernilai -10,239. hal ini berarti apabila profitabilitas naik sebesar 1 persen dengan asumsi variabel yang lainnya tetap, maka diikuti penurunan nilai perusahaan sebesar 10,239. 
5. Koefisien Regresi Variabel pertumbuhan perusahaan bernilai 2.177. Hal ini berarti apabilapertumbuhan perusahaan naik sebesar 1 persen dengan asumsi variabel yang lainnya tetap, maka diikuti kenaikan nilai perusahaan sebesar 2,177
6. Koefisien Regresi Variabel Firm size bernilai 0,520. Hal ini berarti apabila firm size naik sebesar 1 persen dengan asumsi variabel yang lainnya tetap, maka diikuti kenaikan nilai perusahaan sebesar 0,520

Tabel 7. Uji Kelayakan Model

\begin{tabular}{|l|l|l|l|l|l|}
\hline \multicolumn{1}{|c|}{ Hipotesis } & \multicolumn{1}{c|}{ Fhitung } & \multicolumn{1}{c|}{ F table } & Sig & Syarat & Keputusan \\
\hline $\mathrm{Ha}$ & 2,294 & 2,438 & 0,598 & $<0,05$ & Simultan \\
\hline
\end{tabular}

Sumber: Diolah dari SPSS 21, 2020

Berdasarkan pada tabel 7, besar dari 0,05. Hal ini menunjukkan diperoleh $\mathrm{F}$ hitung sebesar 2,294 < F bahwa variabel independen tabel sebesar 2,438 dan signifikansi signifikansi secara bersama-sama tidak sebesar 0,598>0,05 sehingga terlihat bahwa nilai signifikansi tersebut lebih berpengaruh terhadap variabel dependen.

Tabel 8. Uji Hipotesis

\begin{tabular}{|l|l|l|l|l|l|}
\hline Hipotesis & \multicolumn{1}{c|}{ T Hitung } & \multicolumn{1}{c|}{ T tabel } & \multicolumn{1}{c|}{ Sig } & Syarat & Kesimpulan \\
\hline $\mathrm{H}_{1}$ & 1,577 & 2,325 & 0,122 & $<0,05$ & Ditolak \\
$\mathrm{H}_{2}$ & 1,370 & 2,325 & 0,178 & $<0,05$ & Ditolak \\
$\mathrm{H}_{3}$ & $-0,803$ & 2,325 & 0,026 & $<0,05$ & Diterima \\
$\mathrm{H}_{4}$ & 0,966 & 2,325 & 0,340 & $<0,05$ & Ditolak \\
$\mathrm{H}_{5}$ & 0,656 & 2,325 & 0,515 & $<0,05$ & Ditolak \\
\hline
\end{tabular}

Sumber: Diolah dari SPSS 21, 2020

Berdasarkan tabel 8 maka uji hipotesis (uji t) sebagai berikut:

\section{$\mathrm{H}_{1}$ : Likuiditas berpengaruh terhadap nilai perusahaan}

Berdasarkan hasil pengujian uji t diperoleh $\mathrm{t}$ hitung untuk variabel Likuiditas sebesar 1,577 yang artinya $\mathrm{t}$ hitung < t tabel $(1,577<2,325)$ dan nilai signifikansi sebesar 0,122 yang artinya nilai signifikansi >0,05 $(0,122>0,05)$ maka ditarik kesimpulan bahwa likuiditas tidak berpengaruh signifikan terhadap nilai perusahaan.

Hasil penelitian ini menunjukkan bahwa likuiditas tidak berpengaruh signifikan terhadap nilai pweusahaan sehingga dapat disimpulkan bahwa $\mathrm{H}_{0}$ diterima dan $\mathrm{H}_{1}$ ditolak.

\section{$\mathrm{H}_{2}$ : Pengaruh struktur modal terhadap nilai perusahaan}


Berdasarkan hasil pengujian uji $\mathrm{t}$ diperoleh $\mathrm{t}$ hitung untuk variabel struktur modal sebesar 1,370 yang artinya t hitung $>\mathrm{t}$ tabel $(1,370<2,325)$ dan nilai signifikansi sebesar 0,178 yang artinya nilai signifikansi >0,05 $(0,178>0,05)$ maka ditarik kesimpulan bahwa struktur modal tidak berpengaruh signifikan terhadap nilai perusahaan.

Hasil penelitian menunjukkan bahwa struktur modal tidak berpengaruh signifikan terhadap nilai perusahaan sehingga disimpulkan bahwa $\mathrm{H}_{0}$ diterima dan $\mathrm{H}_{2}$ ditolak.

\section{$\mathrm{H}_{3}$ : Profitabilitas berpengaruh terhadap nilai perusahaan}

Berdasarkan hasil pengujian uji $\mathrm{t}$ diperoleh $\mathrm{t}$ hitung untuk variabel profitabilitas sebesar $-0,803$ yang artinya $\mathrm{t}$ hitung $<\mathrm{t}$ tabel $(-0,803<2,325)$ dan nilai signifikansi sebesar 0,026 yang artinya nilai signifikansi $<0,05(0,026<$ 0,05) maka ditarik kesimpulan bahwa profitabilitas berpengaruh signifikan terhadap nilai perusahaan.

Hasil penelitian menunjukkan bahwa profitabilitas berpengaruh signifikan terhadap nilai perusahaan sehingga disimpulkan bahwa $\mathrm{H}_{0}$ ditolak dan $\mathrm{H}_{3}$ diterima .

\section{$\mathrm{H}_{4}$ : pertumbuhan perusahaan berpengaruh terhadap nilai perusahaan}

Berdasarkan hasil pengujian uji $\mathrm{t}$ diperoleh $\mathrm{t}$ hitung untuk variabel pertumbuhan perusahaan sebesar 0,966 yang artinya $\mathrm{t}$ hitung $<\mathrm{t}$ tabel $(0,966<$
2,325) dan nilai signifikansi sebesar 0,340 yang artinya nilai signifikansi $>0,05(0,340>0,05)$ maka ditarik kesimpulan bahwa pertumbuhan perusahaan tidak berpengaruh signifikan terhadap nilai perusahaan.

Hasil penelitian menunjukkan bahwa pertumbuhan perusahaan tidak berpengaruh signifikan terhadap nilai perusahaan sehingga disimpulkan bahwa $\mathrm{H}_{0}$ diterima dan $\mathrm{H}_{3}$ ditolak

\section{$\mathbf{H}_{5}$ : Firm Size berpengaruh terhadap nilai perusahaan \\ Berdasarkan hasil pengujian} uji $\mathrm{t}$ diperoleh $\mathrm{t}$ hitung untuk variabel Firm size sebesar 0,656 yang artinya $\mathrm{t}$ hitung $<\mathrm{t}$ tabel $(0,656<2,325)$ dan nilai signifikansi sebesar 0,515 yang artinya nilai signifikansi $>0,05$ $(0,515>0,05)$ maka ditarik kesimpulan bahwa firm size tidak berpengaruh signifikan terhadap nilai perusahaan.

Hasil penelitian menunjukkan bahwa firm size tidak berpengaruh dan signifikan terhadap nilai perusahaan sehingga disimpulkan bahwa $\mathrm{H}_{0}$ diterima dan $\mathrm{H}_{3}$ ditolak. 
Tabel 9. Uji Koefisien Determinasi

\begin{tabular}{|c|c|}
\hline Adjusted R Square & Kesimpulan \\
\hline 0,113 & Berpengaruh sebesar $11,3 \%$ \\
\hline
\end{tabular}

Sumber: Diolah dari SPSS 21, 2020

Diperoleh nilai adjust $R^{2} \quad 11,3 \%$ sehingga dapat disimpulkan bahwa variabel Likuiditas (X1), Struktur Modal (X2), Profitabilitas (X3), Pertumbuhan Perusahaan (X4), dan Firm Size (X5) mempengaruhi Nilai Perusahaan (Y) sebesar $11,3 \%$ dan $88,7 \%$ dipengaruhi oleh factor lain yang tidak diteliti dalam penelitian ini. Dengan demikian maka dapat disimpulkan bahwa keberadaan variabel nilai perusahaan dapat memperlemah atau menurunkan pengaruh variabel Independen terhadap variabel dependen.

\section{KESIMPULAN}

Penelitian ini betujuan untuk menguji pengaruh likuiditas, Struktur modal, Profitabilitas, Pertumbuhan perusahaan, dan Firm size terhadap nilai perusahaan. Penelitian ini menggunakan 12 perusahaan sector makanan dan minuman yang terdaftar di BEI periode tahun 2015-2018. Penentuan sampel ini menggunakan purposive sampling dengan kriteria dan ketentuan tertentu. Berdasarkan hasil analisis menunjukkan bahwa variabel likuiditas tidak berpengaruh terhadap nilai perusahaan.

Berdasarkan hasil penelitian menunjukkan bahwa Struktur modal tidak berpengaruh terhadapnilai perusahaan. Berdasarkan hasil penelitian menunjukkan bahwa Profitabilitas berpengaruh terhadap nilai perusahaan.
Berdasarkan hasil penelitian menunjukkan bahwa pertumbuhan perusahaan tidak berpengaruh terhadap nilai perusahaan. Berdasarkan hasil penelitian menunjukkan bahwa Firm Size tidak berpengaruh terhadap nilai perusahaan.

\section{SARAN}

Berdasarkan kesimpulan pada penelitian ini, maka dapat disimpulkan beberapa saran sebagai berikut :

1. Bagi peneliti selanjutnya diharapkan dapat menambah populasi tidak hanya pada sektor makanan dan minuman dan masa periode yang lebih lama agar memperkuat hasil penelitian.

2. Bagi peneliti selanjutnya diharapkan dapat menambah variabelvariabel lain agar dapat memperkuat hasil penelitian.

\section{DAFTAR PUSTAKA}

Agustina, M. T., \& Tarigan, J. (2017). Pengaruh Institutional Ownership Financial Performance dengan Intelectual Capital 
Sebagai Variabel Intervening pada Perusahaan Manufaktur yang Terdaftar di Bursa Efek Indonesia. Akuntansi Bisnis, 637-648.

Febrianti, M. (2012). Faktor-faktor yang Mempengaruhi Nilai Perusahaan pada Industri Pertambangan di Bursa Efek Indonesia. Jurnal Bisnis Dan Akuntansi, 14(2), 141156.

Hidayah, N. E., \& Rahmawati. (2019). The Effect of Capital Structure, Profitability, Institutional Ownership and Liquidity on Firm Value. Indonesian Journal of Contemporary Management Research, Vol 1 No 1.

Kayobi, I. G., \& Anggraeni, D. (2015). Pengaruh Debt to Equity Ratio (DER), Debt to Total Asset (DTA), Dividen Tunai, dan Ukuran Perusahaan terhadap Nilai Perusahaan. Jurnal Akuntansi dan Keuangan, 100-120.

Mas'ud, M. (2009). faktor-faktor Penentu Struktur Modal serta Dampaknya terhadap Nilai Perusahaan (Studi pada Perusahaan Manufaktur yang Terdaftar di Bursa Efek Indonesia dan Bursa Efek Malaysia). Jurnal Aplikasi Manajemen, 7(1), 151161.

Natalia, Erlina, \& Muda, I. (2018). Effect Of Capital Structure, Company Growth And Profitability Of Corporate Values In Coal Mining Subsector Companies.

Navissi, F., \& Naiker, F. (2006). Retrieved from Institutional Ownership and Corporate Value: https://doi.org/10.1108/0307435061 0646753

Pratiwi, Yuni, N. P., Yuniatmaja, F., \& Suwendra, I. W. (2016). Effect of Capital Structure and Company Size on Company Values. EJournal Bisma, (4): 1-8.
Senata, M. (2016). Pengaruh Kebijakan Dividen terhadap Nilai Perusahaan yang Tercatat pada Indeks LQ-45 Bursa Efek Indonesia. Jurnal Wira Ekonomi Mikroskil, Vol 6.

Wijoyo, A. (2018). Faktor-faktor yang mempengaruhi nilai perusahaan pada perusahaan property dan real estate di Bursa Efek Indonesia. Jurnal Ekonomi, 48-61. 